\title{
THE USE OF TECHNICAL ANIMATION AND 3D IN TECHNICAL EDUCATION AT SECONDARY SCHOOLS AND UNIVERSITIES
}

\section{Pavel PECINA}

\begin{abstract}
The article is devoted to the technical problem of using animation and $3 D$ technology in technical education. In the first part, we focused on defining the problem. Furthermore, we and the ability to create $3 D$ animations and their use in technical training.
\end{abstract}

Key words: Animation, 3D, Wink, Blender.

\section{PROBLEMATIKA VYUŽITÍ TECHNICKÝCH ANIMACÍ A 3D V TECHNICKÉM VZDĚLÁVÁNÍ NA STŘEDNÍCH A VYSOKÝCH ŠKOLÁCH}

Resumé: Článek je věnován problematice využití technických animací a technologií 3D v technickém vzdělávání. V první části jsme se zaměřili na vymezení problému. Dále se věnujeme možnostem tvorby animací a 3D a jejich využitím v technickém vzdělávání.

Kličcová slova: Animace, 3D, wink, blender.

\section{1 Úvod}

$\mathrm{V}$ posledních deseti letech nastal velmi dynamický rozvoj informačních technologií. Tyto technologie dnes představuji platformu, která zasáhla do všech oblastí lidské činnosti. Jejich vliv stále více zasahuje do edukační činnosti na základních, středních i vysokých školách. Jejich využívání vnáší do pedagogiky nový rozměr, který můžeme označit jako mediální názornost (Vaněček, 2008). Dostupnost těchto prostředků je stále větší, protože průběžně klesá cena mnoha př́strojů i programů a některé využitelné programy jsou dostupné zdarma (viz. dále). Běžně se dnes využívají výukové prezentace obohacené o multimediální prvky (zvukové, obrazové). Základní prostředky těchto technologií ve vzdělávacím systému můžeme rozdělit do následujících skupin (Vaněček, 2008):

- Systémy využití počítačů ve výuce (prezentace látky, procvičování, zkoušení, audio a video technika).

- Rídící systémy (řízení vybavení učeben a laboratoří).

- Interaktivní tabule.

- Videokonference.

- 3D projekce.

- Animace a simulace ve výuce technických předmětů.

- Elektronické vzdělávání a E- learning.

Relativně novými a rychle se rozvíjejícími fenomény jsou oblasti využití technických animací a technologií 3D, na které se dále zaměříme. V odborném technickém vzdělávání na středních a vysokých školách mají tyto prostředky specifické a relativně silné využití. V budoucnu lze očekávat jejich další rozšiřrování $\mathrm{v}$ technických i jiných oborech.

\section{Technické animace}

Technické animace animují (předvádí zpomaleně nebo i zrychleně) různé činnosti, procesy, procedury. Jejich použití je vhodné $\mathrm{v}$ príípadech, kdy slovní podání $\mathrm{v}$ kombinaci se statickým obrazem není dostačující. Ve výuce odborných (technických) předmětů mají široké uplatnění. Jejich základní didaktické funkce jsou následující (Vaněček, 2008) :

- Pochopení zákonitostí nějakého procesu. Jejich záměrem je demonstrovat studovaný jev s dưrazem na maximální názornost a srozumitelnost.

- Simulace fyzikální technických jevů, procesů.

- Ilustrace, motivace. Napomáhají uvědomit si širší souvislosti a zařadit daný problém do širšího celku. V tomto př́padě jsou vhodné animace $\mathrm{k}$ úvodu do problematiky, kdy se animuje např. větší celek, zařízení, systém, děj, od kterého jdeme k detailům, které zajišt'ují jeho chod.

- Procvičování a prověrování látky.

Animace mohou předvádět funkci např. elektronické součástky nebo zapojení, práci $\mathrm{s}$ programem, princip činnosti technického zařízení apod. Konkrétní realizace animace se odvíjí od výukového cíle, $\mathrm{k}$ jehož dosažení má animace pomoci. 


\section{Možnosti řešení tvorby animací}

Existuje více možností, jak řešit tvorbu animace. Programátoři mohou řešit tvorbu animace pomocí programovacích vývojových nástrojů $(\mathrm{C}++$, Java, NET studio, program FLASH, 3ds studio max, Cinema 4D a další). Toto jsou však nástroje pro opravdové programátory. Např. program FLASH Professional umožňuje vytvořit animaci $\mathrm{z}$ jakékoliv autorovy grafické představy. Je to mocný vývojový nástroj, se kterým se setkáme zejména na Internetu. FLASH je relativně rozšířen a jsou odborníci, kteří se zabývají specializovaně problematikou tvorby multimediálních distančních opor $\mathrm{v}$ tomto nástroji (Hrbáček, 2007, Hrbáček, 2008, Hrbáček, 2009, Kučera, Hrbáček, 2009). Zvládnutí práce $\mathrm{s}$ tímto nástrojem stejně jako zvládnutí práce $\mathrm{s}$ jakýmkoliv jiným programovacím nástrojem však vyžaduje stovky hodin soustavné cílevědomé systematické práce.

Jednoduché animace lze vytvářet $\mathrm{v}$ oblíbeném a rozšířeném prezentačním programu Power point. Snadno lze zajistit rotaci vloženého tvaru, pohyb po vybrané dráze (kruh, elipsa, čtverec, př́mka apod.) nebo i nakreslit pohyb podle potřeby. Možnosti tohoto programu jsou v tomto ohledu velmi omezené, avšak je snadno zvládnutelný a disponuje i základní interaktivitou (tlačítka akcí).

Dalším jednoduchým a finančně nenáročným řešením tvorby určitých typů animace je program Wink. Je to zdarma dostupný program, který vytvoří animaci prímo ze snímků obrazovky počítače. Program nafotí cokoliv, co se děje na obrazovce počítače a vytvoří $\mathrm{z}$ toho animaci. V tomto programu tedy lze vytváŕet animace vysvětlující např. práci s příslušným programem (informatika, programování, kurz grafiky, technické kreslení, účetní programy, tvorba prezentací apod.). Do animace lze vkládat text i zvukový komentář. Animace se může udělat také z posloupnosti obrázků (JPG, GIF), nejen z posloupnosti snímků $\mathrm{z}$ obrazovky počítače. Výsledná animace se dá exportovat ve formátu FLASH a má tedy stejné výhody jako FLASH animace. Práce s programem Wink není složitá a lze ji zvládnout velmi rychle a snadno. $\mathrm{V}$ době psaní této studie bylo možné na Internetu vyhledat návod na práci $\mathrm{s}$ tímto programem. (http://freenavody.wz.cz/wink/Wink1.html).

Program Blender je opět volně šiřitelný program, který lze stáhnout z Internetu. Tento program pro tvorbu 3D grafiky disponuje kromě prostředků pro tvorbu animovaných obrázků, filmů i her poměrně silnými nástroji pro tvorbu animací. Existuje $\mathrm{k}$ němu i literatura $\mathrm{v}$ českém jazyce a mnoho materiálů lze nalézt na Internetu (Pokorný, 2009). Tento nástroj je relativně snadno zvládnutelný a umožnuje tvorbu animací bez znalosti programování. Možné je animovat a simulovat oheň, kouř, vítr, trávu, kapaliny, pohyby částic, pohyby různých objektů, deformace tvarů a mnoho dalšího (Pokorný, 2009). Program Blender se neustále vyvíjí už od roku 2003 a k dispozici jsou zdarma průběžně nové a dokonalejší verze tohoto programu. $\mathrm{V}$ době psaní této publikace to byla verze $2.56 \mathrm{a}$. Na Obr. 1 níže máme ukázku 3D scény vytvořené $\mathrm{v}$ Blenderu.

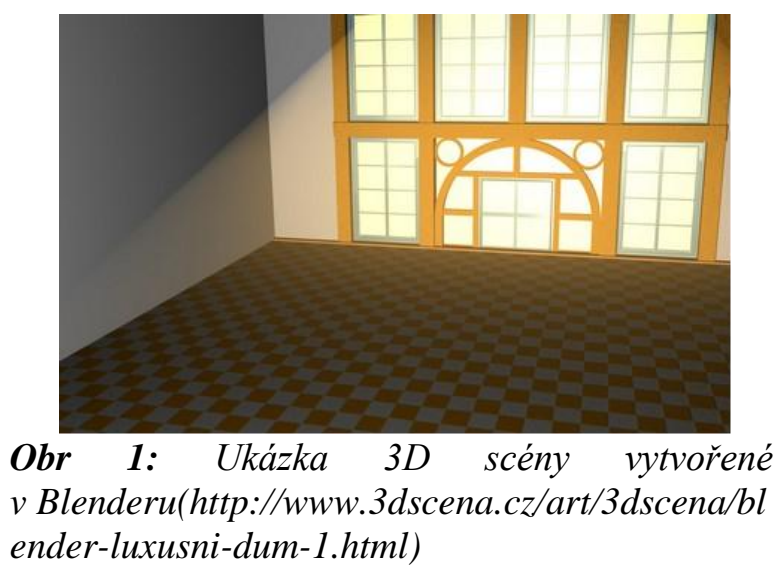

Dalšími komerčními nástroji pro tvorbu animací jsou Solidworsk (modul pohybové animace), Invertor r. 12 (simulace pohybu), Pro/Engineer WildFire 5 (pohybová analýza a optimalizace). Tyto prostředky umožnují rozšířené a specializované funkce pro tvorbu animací ( http://www.solidvision.cz/solidworks/).

\section{Technologie 3D}

Revoluční 3D technologie představuje zcela novou dimenzi názornosti ve výuce. Umožňuje zobrazit prostorový obraz, který se snažíme co nejlépe přiblížit realitě. Tato technologie se využívá $\mathrm{v}$ kinech a na našem trhu jsou již $\mathrm{k}$ dispozici i 3D televize. Zatím je však tato technika relativně drahá a nedostupná. Také 3D pořadů je zatím málo. Vývoj $\mathrm{v}$ této oblasti však jde rychle dopředu a velmi brzy budou běžně $\mathrm{k}$ dispozici 3D televize, mnoho pořadů a očekávat lze také její využívání ve výuce. Dnes již existují možnosti, jak zobrazit prostor. Je k tomu třeba stereoskopický systém založený na rozdílných polarizacích světla. Princip funkce spočívá v tom, že používáme dva zdroje obrazu- jeden pro pravé oko a druhý pro levé oko. Dále je třeba zajistit 
vnímání každým okem ten správný obraz. To se realizuje pomocí speciálních filtrů v projektorech a sklech v brýlích pozorovatelů. $\mathrm{V}$ současné době se pracuje na vývoji technologií, které umožní sledovat 3D obraz bez speciálních brýlí. Touto technikou docílíme toho, že vnímáme prostorový obraz např. $\mathrm{v}$ učebně, který tam reálně není. Pomocí př́íslušných programů můžeme $\mathrm{s}$ objektem různě otáčet a měnit jeho vlastnosti (Vaněček, 2008). Napřr. můžeme zobrazit nějaký výrobek, prototyp, u kterého měníme barvu, tvar, části a součástky apod. Můžeme také nahlédnout dovnitř a zkoumat budoucí podobu výrobku, např̀. domu, automobilu apod.

Technologie 3D se dnes využíá zejména na specializovaných pracovištích, které se zabývají virtuální realitou a počítačovým modelováním. Lze však očekávat její brzkou dostupnost i ve školách technického zaměření a nejen tam. Naše pracoviště spolupracuje $\mathrm{s}$ Integrovanou střední školou automobilní, Křžíkova, Brno, která je naší fakultní školou (http://www.issabrno.cz lindex.php). V rámci inovace výuky kolegové na této stř̌ední škole vytvárí e- learningové výukové opory $\mathrm{v}$ prostředí Moodle a využívají také technologii 3D zobrazování. Předmětem zájmu 3D se stal projekt 3D - PLP M (Dimensional performance learning platform for motocycle mechanics). Tento projekt začali kolegové řešit před čtyřmi lety a jeho výstupem je vzniklá metodika, využívající 3D technologií virtuální reality (Krejčí, 2011, s. 8). Materiály jsou určeny pro výuku oboru mechanik jednostopých vozidel (Krejčí, 2011). Trojrozměrnými objekty lze jakkoliv pohybovat pomocí animace, otáčet a u celků lze jednotlivé části rozkládat a skládat (Krejčí, 2011). Výstupy tohoto projektu vznikaly tak, že pedagogové co nejlépe popsali požadavek na budoucí 3D vizualizaci a počítačoví odborníci je podle požadavku zpracovali a vytvořili výslednou 3D projekci (Krejčí, 2011).

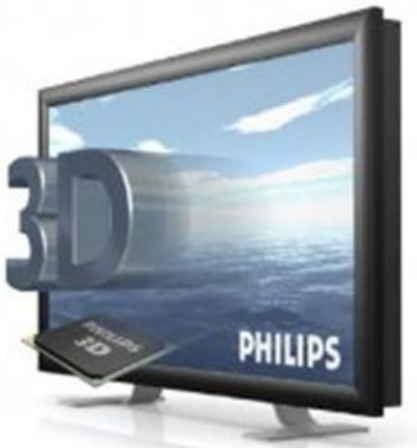

Obr 2: Ukázka 3D obrazu

(http://www.digitalnidomacnost.cz/3d-televizebez-bryli-a-nebo-rovnou-4d/)
Jak jsme naznačili dř́ive, je možné př́slušnou technikou např. zobrazit jakýkoliv nástroj, stávající nebo budoucí výrobek, systém a různě $\mathrm{s}$ ním manipulovat. Můžeme zobrazovat strojní součásti, modely např. stroje, automobilu nebo jakéhokoliv jiného prototypu budoucího výrobku. U objektů můžeme měnit barvu, tvar, velikost, části apod. Tyto možnosti zkracují vývoj a také šetří náklady na vývoj (Vaněček, 2008). Tyto prostředky lze využití i při běžné konstrukční činnosti $\mathrm{v}$ technickém vzdělávání na všech stupních škol.

\section{Závěr}

Výše popsané fenomény v současné době zažívají rychlý vývoj a budou stále dostupnější a využitelnější. Bohužel zatím nemáme $\mathrm{k}$ dispozici soustavnější prameny, které by dokládaly efektivitu těchto prostředků oproti tradičním výukovým prostředkům. $\mathrm{V}$ případě technologie 3D se jedná spíše o budoucnost i když prvotní zkušenosti již máme (Krejčí, 2011). V př́ípadě technických animací máme $\mathrm{k}$ dispozici vlastní zkušenosti i některá zjištění o jejich pozitivním př́nosu ve výuce (Hrbáček, 2007, Hrbáček, 2008). Na úrovni pedagogiky a oborové didaktiky technických předmětů je třeba vývoj $\mathrm{v}$ této oblasti sledovat a zabývat se možnostmi jejich využití bez nutnosti učit se programovat nebo zvládat tyto technologie ve větším rozsahu. $\mathrm{Z}$ pedagogického hlediska to jsou pomocné prostředky $\mathrm{k}$ dosažení stanovených cílů (pokud se cíleně těmito prostředky nezabýváme). Úkolem pedagoga je tedy projektovat a navrhovat možnosti jejich využití, př́padně zvládnout některé jednodušší nástroje - Wink, Blender apod. Z tohoto pohledu je nutná a potřebná spolupráce učitelů technických předmětů $\mathrm{s}$ odborníky $\mathrm{z}$ této oblasti. Technickou stránku problému musí řešit informatici, programátoři a lidé zabývajícími se př́slušnou oblastí elektroniky.

$\mathrm{V}$ další práci $\mathrm{v}$ této oblasti se chceme zaměřit na další možnosti těchto technologií (využitelné programy pro tvorbu animací, 3D, 4D apod.). $\mathrm{V}$ prripravovaných studijních materiálech do didaktiky odborných technických předmětů máme i některé ukázky jednodušších animací vytvořených v programu Wink a Blender. Dále se chceme zaměřit na konkrétní modely animací pro výuku technických předmětů. Naše návrhy chceme ověrit pedagogickým experimentem nebo př́ípadně akčním výzkumem na některé fakultní střední odborné technické škole v Brně, případně 
v rámci výuky vybraných technických předmětů na katedře technické a informační výchovy Pedagogické fakulty Masarykovy univerzity.

\section{Literatura}

[1] HRBÁČEK, J. Využití Flash animací ve výukových oporách In XX DIDMATTECH. Olomouc: Univerzita Palackého, 2007. ISBN 807220 -296-0.

[2] HRBÁČEK, J. Způsoby tvorby Flash animací pro studijní opory In. Alternativní metody výuky, sbornik príspěvků. Hradec Králové: Gaudeamus, 2008. ISBN 978-80-7041-454-5

[3] KONUPČÍK, P. Didaktické technologie pro pedagogické pracovniky. Brno: MU, 2002.

[4] KŘIŽ, J. 3ds max 6 Praktické postupy. Brno: Computer Press, 2004. ISBN 80-251-0329-3.

[5] KUČERA, M., HRBÁČEK, J. Možnosti propojení Flash animací s měrícími systémy pro podporu výuky In. Nové technologie ve výuce, sbornik abstraktio a elektronických verzi př́spěvků. Brno: PdF MU, 2009. ISBN 978- 80210-5092-1.

[6] KREJČÍ, P. Inovace ŠVP Mechanik jednostopých vozidel. Bakalářská práce. Brno: Masarykova univerzita, Pedagogická fakulta, Katedra didaktických technologií, 2011. Vedoucí bakalářské práce. Ing. Milan Chylík
[7] POKORNÝ, P. BLENDER naučte se $3 D$ grafiku. Praha: BEN, 2009. ISBN 978 - 80 $7300-244-2$.

[8] VANĚČEK, D. Informační a komunikačni technologie ve vzdělávání. Praha: ČVUT, 2008. ISBN 978-80-01-04087-4.

\section{Internetové zdroje:}

http://freenavody.wz.cz/wink/Wink1.html

http://www.3dscena.cz/art/3dscena/blender-

luxusni-dum-1.html)

http://www.issabrno.cz/index.php http://www.solidvision.cz/solidworks/ http://www.digitalnidomacnost.cz/3d-televizebez-bryli-a-nebo-rovnou-4d/)

Mgr. Pavel Pecina, Ph.D.

Masarykova univerzita

Pedagogická fakulta

Katedra didaktických technologií

Poříčí 31

602 00, Brno

Česká republika

Telefon: +420 549495488

Mail: ppecina@ped.muni.cz 